DOI: $10.1515 /$ pts-2017-0042

ELECTRONICS

\title{
COMPARISON OF CHROMATIC DISPERSION COMPENSATION METHOD EFFICIENCY FOR 10 GBIT/S RZ-OOK AND NRZ-OOK WDM-PON TRANSMISSION SYSTEMS
}

\author{
A. Alsevska, V. Dilendorfs, S. Spolitis, Vj. Bobrovs \\ Institute of Telecommunications, Riga Technical University, \\ 12 Azenes Str., Riga, LV-1048, LATVIA \\ E-mail: Valts.Dilendorfs@rtu.lv
}

\begin{abstract}
In the paper, the authors compare efficiency of two physical dispersion compensation methods for single channel and 8-channel WDM fibreoptical transmission systems using return-to-zero (RZ) and non-return-to-zero (NRZ) line codes for operation within optical C-band frequencies by means of computer simulations. As one of the most important destructive effects in fibre optical transmission systems (FOTS) is chromatic dispersion (CD), it is very important to reduce its negative effect on a transmitted signal. Dispersion compensation methods that were implemented in the research were dispersion compensating fibre (DCF) and fibre Bragg grating (FBG). The main goal of the paper was to find out which dispersion compensation method (DCF or FBG) provided the highest performance increase for fibre-optical transmission system and provided the longest transmission distance after dispersion compensation was implemented at different locations in the fibre-optical line while RZ or NRZ line codes were used. In the paper the reference point of signal quality for all measurements, which were obtained at the receiver, was BER $<10^{-12}$.
\end{abstract}

Keywords: DCF, DCM, dispersion, dispersion compensation, $F B G$, optical access, optical fibre, SMF, WDM-PON

\section{INTRODUCTION}

The development of telecommunication systems in the near future is focused on the increasing data transmission speeds for all kinds of electronic devices, especially wireless devices. Mobile network operators are still heavily interested in improving mobile network from $3 \mathrm{G}$ to $4 \mathrm{G}, 4 \mathrm{G}+$ and preparing for $5 \mathrm{G}$. While transmission speeds and service coverage areas increase, wireless network operators are still unable to provide sufficient transmission speed and quality as fibre-optical connection can. There are a number of compelling advantages for using fibre-optics, for example, fibre-optic cabling provides a much higher bandwidth, fibre-optics do not suffer from intersymbol interference and have much lower levels of signal attenuation [1]. 
One solution for efficient utilisation of fibre optical network in urban areas without the need for installing additional optical fibres to backbone network is adopting dense wavelength division multiplexing (DWDM) transmission systems. DWDM is a transmission system that enables more efficient utilisation of optical fibre by multiplexing and simultaneously transmitting multiple optical signals of different wavelengths [2]. Even though the fibre optical transmission systems (FOTS) are the backbone of all worlds' communications, system itself has undesirable effects which are necessary to prevent or reduce. The most common destructive effect for FOTS is chromatic dispersion (CD). CD is the term given to the phenomenon by which different spectral components of a pulse travel at different velocities. The negative effect of CD in FOTS increases with the increase of bit rate or optical fibres length. When one or both conditions are fulfilled the effect of CD must be taken into consideration but if it is ignored, dispersion can completely corrupt transmitted data because of intersymbol interference (ISI) [3].

There are many methods how to compensate $\mathrm{CD}$, but two the most popular methods are dispersion shifted fibre (DCF) and fibre Bragg grating (FBG) [3]- [4]. $\mathrm{DCF}$ and FBG detailed explanation are written in the second section.

When higher bit rates such as $10 \mathrm{Gbit} / \mathrm{s}$ and above and/or high transmitted powers are transmitted, it is important to consider the influence of nonlinear optical effects (NOE). In the case of WDM systems, nonlinear effects can become important even at moderate powers and bit rates. NOE are often categorised into two categories of nonlinear effects. The first arises due to the interaction of light waves with phonons in the silica medium. The main effects in this category are stimulated Brillouin scattering (SBS) and stimulated Raman scattering (SRS). The second set of nonlinear effects arises due to dependence of the refractive index on the intensity of the applied electric field. The most important NOE in this category are self-phase modulation (SPM) and four wave mixing (FWM) [3]. Single-channel nonlinear effects manifest mainly through self-phase modulation (SPM), whereby each channel alters its own phase. SPM translates into pulse distortions through chromatic dispersion [3], [5]. WDM nonlinear effects are often split into cross phase modulation (XPM), whereby the phase of each channel is modified by the power of the neighbouring channels, and four wave mixing (FWM), whereby three channels interact to transfer a fraction of their energy to a fourth one [3], [6]. Due to previously mentioned destructive influence on FOTS performance, the maximal transmission line length, with $10 \mathrm{Gbit} / \mathrm{s}$ transmission speed, is less than $100 \mathrm{~km} \mathrm{[7].}$

Within the framework of the research, non-return-to-zero (NRZ) and return-to-zero (RZ), the most common on-off keying (OOK) signal line codes, were studied. The most common line code - NRZ for 1 bit representation occupies the entire bit interval at constant power level. RZ is another common line code which occupies only a fraction of the bit interval that depends on a duty cycle. Typical duty cycle is $50 \%$. If NRZ and RZ line code bandwidths are compared, then it is possible to determine that RZ line code occupies about half larger bandwidth than NRZ line code and this is also the main difference between NRZ and RZ [8]. RZ line code has also greater tolerance to nonlinear effects like - SPM, XPM and FWM. On the one hand, the NRZ line code is more suitable for WDM systems; on the other hand, the RZ line code is found to be less susceptible to inter-symbol interference (ISI) due to 
a smaller impact of NOE and so typically achieves better performance compared to NRZ [9].

The main purpose of this paper is to investigate the most popular dispersion compensation methods - DCF and FBG for dispersion compensation efficiency using RZ and NRZ line codes for single- and 8-channel transmission systems with 10 $\mathrm{Gbit} / \mathrm{s}$ transmission speed.

In the beginning, simulations of dispersion compensation are executed for a single channel system, but then simulations are repeated for 8- channel WDM FOTS with $100 \mathrm{GHz}$ channel spacing. The paper shows how fibre-optical transmission systems with RZ or NRZ line code are affected by different dispersion compensation methods and also how dispersion compensation location in a fibre-optical transmission line influences the length of fibre-optical transmission lines.

\section{DISPERSION COMPENSATION METHODS}

Dispersion is the name given to any effect wherein different components of the transmitted signal travel at different velocities in the fibre, arriving at different times at the receiver. A signal pulse launched into a fibre arrives smeared at the other end as a consequence of this effect. Dispersion is a cumulative effect - the longer the link, the greater the amount of dispersion. Standard single mode fibre (SMF) has a positive dispersion value of around $16 \mathrm{ps} /(\mathrm{nm} \cdot \mathrm{km})$ at $1550 \mathrm{~nm}$. The destructive impact of CD increases if FOTS transmissions speed is also increased, particularly for system with $10 \mathrm{Gbit} / \mathrm{s}$ bit rate or higher [7].

Dispersion management is a very important part of designing WDM transmission systems, since dispersion affects the penalties due to various types of fibre nonlinearities. There are several techniques to reduce the impact of CD - external modulation in conjunction with DFB lasers, use of fibre with small chromatic dispersion value, and chromatic dispersion compensation [2]. In the present paper, the main objective is to investigate chromatic dispersion compensation with DCF and FBG. The two most common methods can be used as dispersion-compensating module (DCM) for dispersion compensation purposes.

DCF is special fibre developed for CD compensation. DCF has a negative dispersion value of around $-80 \mathrm{ps} /(\mathrm{nm} \cdot \mathrm{km})$ (SMF has a positive value of $16 \mathrm{ps} /$ $(\mathrm{nm} \cdot \mathrm{km}))$ at $1550 \mathrm{~nm}$ and core effective area of $20 \mu \mathrm{m}^{2}$ (compared to SMF $85 \mu \mathrm{m}^{2}$. The required amount of dispersion compensation can be calculated by the following equation (1).

$$
D\left(\lambda_{\mathrm{SMF}}\right) L_{S M F}+D\left(\lambda_{D C F}\right) L_{D C F}=0
$$

In equation (1) variables $D\left(\lambda_{S M F}\right)$ and $D\left(\lambda_{D C F}\right)$ are dispersion coefficients ps/ $(\mathrm{nm} \cdot \mathrm{km})$ for single-mode fibre (SMF) and dispersion compensating fibre (DCF) at certain wavelength $(\lambda, \mathrm{nm})$, but $L_{S M F}$ and are the lengths of fibres (in $\mathrm{km}$ ). It is important not to reduce CD value to zero because of FWM increases due to the genera- 
tion of new beat frequencies [10]. Because of wide performance bandwidth, stable performance and minimal temperature dependence, DCF have become one of the most used method for CD compensation. One DCF disadvantage is its large added loss to the system $-0.55 \mathrm{~dB} / \mathrm{km}$.

Part of the fibre where period of the refractive index grating varies along the length of the fibre is called chirped fibre Bragg grating (FBG). When FOTS optical signal propagates through chirped fibre Bragg grating, different wavelength components will get reflected at different positions along the grating. As transmitted optical signal contains different wavelength components and these optical signal components will be reflected, depending on the wavelength, at different positions along the grating, it is possible to use this ability to compensate CD. Dispersion compensation using FBG has some advantages over DCF, for example, FBG is smaller in size physically, exhibits relatively small insertion loss and causes negligible nonlinearities [4]. FBG ideally is suited for individual wavelength compensation rather than multiple wavelengths, but, in contrast, DCF is better suited for compensation over a wide range of wavelengths.

The physical location of optical components inside FOTS can also impact the performance of FOTS. Because of this property, DCM (DCF or FBG) can be placed at three different locations in the transmission system for $\mathrm{CD}$ pre-compensation, post-compensation and symmetrical compensation.

\section{EXPERIMENTAL SIMULATION MODEL}

For experimental simulation, RSoft simulation program OptSim was used. OptSim is widely used for design of high-performance optical communication systems. In the paper, single- and 8-channel WDM system mathematical modelling, with different on-off keying (OOK) modulation formats (RZ and NRZ), was shown, exploring how CD changed the performance of FOTS system when DCM units were implemented in the system.

In the simulation, transmission speed for single-channel and 8-channel systems was set to $10 \mathrm{Gbit} / \mathrm{s}$ per channel. Transmitter, for a single-channel system, was constructed from 4 elements - the data source, RZ or NRZ coder, continuous wave laser $(\mathrm{CW})$ as a light source, Mach-Zehnder amplitude modulator. For an 8-channel system, additional optical Raised-Cosine filter was added with $60 \mathrm{GHz}$ bandwidth at $-3 \mathrm{~dB}$ and 0.1 roll-off factor. For a single-channel system, two central frequencies of different channels were chosen - 193.1 THz and 195.9 THz. For 8-channel simulations, central frequencies were chosen starting from the 1 st to the 8 th channel, again two different frequency bandwidths were chosen and they ranged from $193.1 \mathrm{THz}$ to $193.8 \mathrm{THz}$ and from $195.9 \mathrm{THz}$ to $196.6 \mathrm{THz}$. Channel frequencies were chosen according to ITU-T G.694.1 recommendation. Receiver, for all channels, was composed of 3 elements - the optical Raised-Cosine filter, PIN receiver diode and fifth order electrical Bessel filter with $8 \mathrm{GHz}$ bandwidth at $-3 \mathrm{~dB}$. Arrayed waveguide grating (AWG) multiplexer and demultiplexer were formed from optical power splitter and combiner together with optical filters [11]. A complete simulation model for an 8-channel WDM system is shown in Fig. 1 and the basic parameters of setup 
components are shown in Table 1.

Simulation model and the basic parameters of components for a single-channel system remain the same if compared with an 8-channel system, the only difference is the removal of excess transmitters, receivers and coupler/splitter.

The main aim at first was to obtain maximum line length for both a singlechannel system and an 8-channel WDM system without dispersion compensation. All simulations were executed for both RZ and NRZ line codes. We chose BER $<10^{-}$ ${ }^{12}$ as the reference threshold for all channels in our investigated transmission systems to determine the maximum line length. After maximum line length was clarified, all simulations were repeated only with one exception -additional DCM modules were added for CD compensation. DCM module consisted of one of the two most common dispersion compensation methods - DCF or FBG. In addition, DCM location was changed in FOTS with the aim of clarifying how the location of DCM would change the performance of individual channels in a single-channel system and an 8-channel WDM system.

At first, simulations were executed for a single-channel system with RZ line code using DCF as DCM in all possible combinations in FOTS. Afterwards, DCF was substituted with FBG and simulations were repeated. Then RZ line code was changed for NRZ line code and simulations for a single-channel system were repeated. The same steps were repeated with simulations of an 8-channel system. In total, 56 simulations were completed.

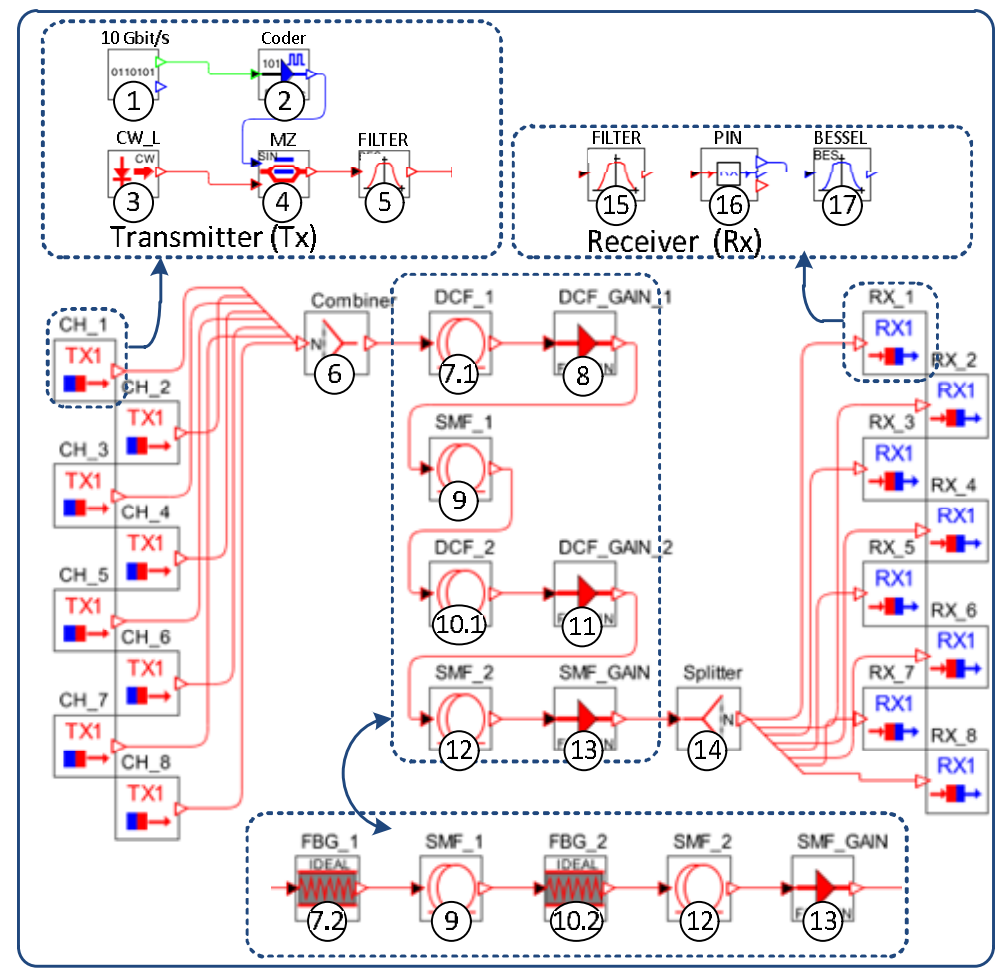

Fig. 1. Simulation model of 8-channel, $10 \mathrm{Gbit} / \mathrm{s}$, optical fibre transmission system with symmetrical CD compensation for SMF. 
Basic Parameter Values for 8-Channel Simulation Model Components

\begin{tabular}{|c|c|c|c|}
\hline No. & Components & $\begin{array}{l}\text { Basic parameters } \\
\text { (1 CHANNEL) }\end{array}$ & $\begin{array}{l}\text { Basic parameters } \\
\text { (8 CHANNELS) }\end{array}$ \\
\hline 1 & Data source & Data rate: $10 \mathrm{Gbit} / \mathrm{s}$ & Data rate: $10 \mathrm{Gbit} / \mathrm{s}$ \\
\hline 2 & Coder (RZ or NRZ) & RZ Duty cycle: 0.5 & RZ Duty cycle: 0.5 \\
\hline 3 & CW laser & $\begin{array}{c}\text { Output power: } 3 \mathrm{dBm} \text {, } \\
\text { FWHM linewidth: } 1 \mathrm{MHz} \\
\text { Central emission frequency: } \\
193.1 \mathrm{THz} \text { or } 195.9 \mathrm{THz}\end{array}$ & $\begin{array}{c}\text { Output power: } 3 \mathrm{dBm} \text {, } \\
\text { FWHM linewidth: } 1 \mathrm{MHz} \\
\text { Channels central frequencies: } \\
1^{\text {st }} \text { to } 8^{\text {th: }} \text { : } \\
193.1 \mathrm{THz}-193.8 \mathrm{THz} \text { or } \\
195.9 \mathrm{THz}-196.6 \mathrm{THz} \\
\text { Channel spacing: } 100 \mathrm{GHz}\end{array}$ \\
\hline 4 & $\begin{array}{l}\text { Mach-Zehnder (MZ) } \\
\text { amplitude modulator }\end{array}$ & Excess loss: $3 \mathrm{~dB}$ & Excess loss: $3 \mathrm{~dB}$ \\
\hline 5 & $\begin{array}{l}\text { Optical Raised- } \\
\text { Cosine filter }\end{array}$ & - & $\begin{array}{c}\text { Roll-off factor: } 0.1 \\
\text {-3dB bandwidth: } 60 \mathrm{GHz}\end{array}$ \\
\hline 6 & Optical combiner & - & Attenuation: $0 \mathrm{~dB}$ \\
\hline 7.1 & DCF fiber Nr.1 & $\begin{array}{l}\text { Loss: } 0.55 \mathrm{~dB} / \mathrm{km} \\
\text { Dispersion: }-80 \mathrm{ps} /(\mathrm{nm} \cdot \mathrm{km}) \\
\text { Core effective area: } 20 \mu \mathrm{m}^{2}\end{array}$ & $\begin{array}{l}\text { Loss: } 0.55 \mathrm{~dB} / \mathrm{km} \\
\text { Dispersion: }-80 \mathrm{ps} /(\mathrm{nm} \cdot \mathrm{km}) \\
\text { Core effective area: } 20 \mu \mathrm{m}^{2}\end{array}$ \\
\hline 7.2 & FBG Nr.1 & $\begin{array}{l}\text { Variable dispersion value, } \mathrm{ps} / \\
(\mathrm{nm} \cdot \mathrm{km})\end{array}$ & $\begin{array}{l}\text { Variable dispersion value, } \mathrm{ps} / \\
(\mathrm{nm} \cdot \mathrm{km})\end{array}$ \\
\hline 8 & $\begin{array}{l}\text { DCF Gain Nr.1 } \\
\text { (EDFA optical am- } \\
\text { plifier) }\end{array}$ & Variable gain, dB & Variable gain, $\mathrm{dB}$ \\
\hline 9 & SMF fiber Nr.1 & $\begin{array}{l}\text { Loss: } 0.2 \mathrm{~dB} / \mathrm{km} \\
\text { Dispersion: } 16 \mathrm{ps} /(\mathrm{nm} \cdot \mathrm{km}) \\
\text { Core effective area: } 80 \mu \mathrm{m}^{2}\end{array}$ & $\begin{array}{l}\text { Loss: } 0.2 \mathrm{~dB} / \mathrm{km} \\
\text { Dispersion: } 16 \mathrm{ps} /(\mathrm{nm} \cdot \mathrm{km}) \\
\text { Core effective area: } 80 \mu \mathrm{m}^{2}\end{array}$ \\
\hline 10.1 & DCF fiber Nr.2 & $\begin{array}{l}\text { Loss: } 0.55 \mathrm{~dB} / \mathrm{km} \\
\text { Dispersion: }-80 \mathrm{ps} /(\mathrm{nm} \cdot \mathrm{km}) \\
\text { Core effective area: } 20 \mu \mathrm{m}^{2}\end{array}$ & $\begin{array}{l}\text { Loss: } 0.55 \mathrm{~dB} / \mathrm{km} \\
\text { Dispersion: }-80 \mathrm{ps} /(\mathrm{nm} \cdot \mathrm{km}) \\
\text { Core effective area: } 20 \mu \mathrm{m}^{2}\end{array}$ \\
\hline 10.2 & FBG Nr.2 & $\begin{array}{l}\text { Variable dispersion value, } \mathrm{ps} / \\
(\mathrm{nm} \cdot \mathrm{km})\end{array}$ & $\begin{array}{l}\text { Variable dispersion value, } \mathrm{ps} / \\
(\mathrm{nm} \cdot \mathrm{km})\end{array}$ \\
\hline 11 & $\begin{array}{l}\text { DCF Gain Nr.2 } \\
\text { (EDFA optical am- } \\
\text { plifier) }\end{array}$ & Variable gain, $\mathrm{dB}$ & Variable gain, $\mathrm{dB}$ \\
\hline 12 & SMF fiber Nr.2 & $\begin{array}{l}\text { Loss: } 0.2 \mathrm{~dB} / \mathrm{km} \\
\text { Dispersion: } 16 \mathrm{ps} /(\mathrm{nm} \cdot \mathrm{km}) \\
\text { Core effective area: } 80 \mu \mathrm{m}^{2}\end{array}$ & $\begin{array}{l}\text { Loss: } 0.2 \mathrm{~dB} / \mathrm{km} \\
\text { Dispersion: } 16 \mathrm{ps} /(\mathrm{nm} \cdot \mathrm{km}) \\
\text { Core effective area: } 80 \mu \mathrm{m}^{2}\end{array}$ \\
\hline 13 & Gain Nr.3 & Gain: $10 \mathrm{~dB}$ & Gain: $10 \mathrm{~dB}$ \\
\hline 14 & Splitter & - & Attenuation: $0 \mathrm{~dB}$ \\
\hline 15 & $\begin{array}{l}\text { Optical Raised- } \\
\text { Cosine filter }\end{array}$ & - & $\begin{array}{c}\text { Roll-off factor: } 0.1 \\
\text {-3dB bandwidth: } 60 \mathrm{GHz}\end{array}$ \\
\hline 16 & Receiver & $\begin{array}{l}\text { Photodiode: PIN } \\
\text { Sensitivity: }-23.9 \mathrm{dBm} \\
\text { Error probability: } 10^{-9}\end{array}$ & $\begin{array}{c}\text { Photodiode: PIN } \\
\text { Sensitivity: }-23.9 \mathrm{dBm} \\
\text { Error probability: } 10^{-9}\end{array}$ \\
\hline 17 & $\begin{array}{l}\text { Electrical Bessel } \\
\text { filter }\end{array}$ & $\begin{array}{l}\text { Number of poles: } 5 \\
\text {-3dB bandwidth: } 8 \mathrm{GHz}\end{array}$ & $\begin{array}{l}\text { Number of poles: } 5 \\
-3 \mathrm{~dB} \text { bandwidth: } 8 \mathrm{GHz}\end{array}$ \\
\hline
\end{tabular}




\section{RESULTS AND DISCUSSION}

When RZ line code was used, the maximum transmission line length for a single-channel system without CD compensation at $193.1 \mathrm{THz}$ was $\mathrm{L}=49.0 \mathrm{~km}$ (accumulated dispersion value $784.0 \mathrm{ps} / \mathrm{nm}, \mathrm{BER}=5.4 \cdot 10^{-13}$ ), but at $195.9 \mathrm{THz} \mathrm{L}=56.4$ $\mathrm{km}$ (accumulated dispersions value $901.9 \mathrm{ps} / \mathrm{nm}, \mathrm{BER}=9.5 \cdot 10^{-13}$ ). While using NRZ line code, the maximum transmission line length for a single channel system without $\mathrm{CD}$ compensation at $193.1 \mathrm{THz}$ was $\mathrm{L}=84.4 \mathrm{~km}$ (accumulated dispersion value $1350.4 \mathrm{ps} / \mathrm{nm}, \mathrm{BER}=6.2 \cdot 10^{-13}$ ), but at $195.9 \mathrm{THz} \mathrm{L}=92.1 \mathrm{~km}$ (accumulated dispersion value $\left.1473.6 \mathrm{ps} / \mathrm{nm}, \mathrm{BER}=8.8 \cdot 10^{-13}\right)$. Further activities for a single-channel system were to completely compensate CD using both DCF and FBG. When CD compensations were performed by DCF, an additional amplifier was used for DCF insertion loss compensation, but FBG insertion loss was set to $0 \mathrm{~dB}$ (in simulation FBG component). At first, $C D$ compensation was executed for a single channel system with RZ line code, at both frequencies, using DCM for pre-compensation, post-compensation and symmetrical compensation, but then $\mathrm{CD}$ compensation was executed for a system with NRZ line code, for the both frequencies as well. A total of 6 different combinations were investigated for each line code formats and each frequency. All results for single-channel system simulations are demonstrated in Table 2.

Table 2

Maximal Provided Transmission Distances for Single-Channel

Communication Systems with RZ and NRZ Line Codes

\begin{tabular}{|c|c|c|c|c|c|c|c|c|}
\hline \multicolumn{9}{|c|}{ SINGLE-CHANNEL, RZ line code } \\
\hline 冚 & 巳 & 泀 & 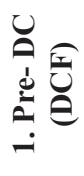 & 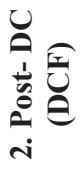 & 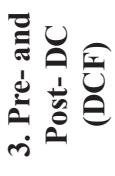 & 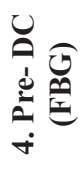 & 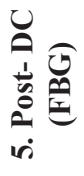 & 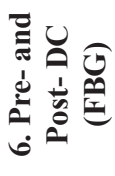 \\
\hline \multirow{3}{*}{$\begin{array}{l}193.1 \\
\text { THz }\end{array}$} & Max. line length, km & 49.0 & 97.2 & 97.2 & 97.3 & 97.3 & 97.5 & 97.6 \\
\hline & Extension length, km & & 48.2 & 48.2 & 48.3 & 48.3 & 48.5 & 48.6 \\
\hline & Extension length, \% & - & 49.6 & 49.6 & 49.7 & 49.7 & 49.7 & 49.8 \\
\hline \multirow{3}{*}{$\begin{array}{l}195.9 \\
\text { THz }\end{array}$} & Max. line length, km & 56.4 & 117.1 & 116.8 & 115.6 & 116.5 & 115.8 & 115.5 \\
\hline & Extension length, km & & 60.7 & 60.4 & 59.2 & 60.2 & 59.5 & 59.2 \\
\hline & Extension length, \% & - & 51.9 & 51.7 & 51.2 & 51.6 & 51.3 & 51.2 \\
\hline \multicolumn{9}{|c|}{ SINGLE-CHANNEL, NRZ line code } \\
\hline \multirow{3}{*}{$\begin{array}{l}193.1 \\
\mathrm{THz}\end{array}$} & Max. line length, km & 84.4 & 157.8 & 157.6 & 157.7 & 155.7 & 156.8 & 156.9 \\
\hline & Extension length, km & & 73.4 & 73.2 & 73.3 & 71.3 & 72.4 & 72.5 \\
\hline & Extension length, \% & - & 46.5 & 46.5 & 46.5 & 45.8 & 46.2 & 46.2 \\
\hline \multirow{3}{*}{$\begin{array}{l}195.9 \\
\mathrm{THz}\end{array}$} & Max. line length, km & 92.1 & 148.7 & 145.1 & 146.5 & 147.9 & 147.3 & 147.3 \\
\hline & Extension length, km & & 56.6 & 53.0 & 54.4 & 55.8 & 55.2 & 55.2 \\
\hline & Extension length, \% & - & 38.1 & 36.5 & 37.1 & 37.7 & 37.5 & 37.5 \\
\hline
\end{tabular}

When RZ line code was used, the longest optical line for a single-channel system at $193.1 \mathrm{THz}$ was $\mathrm{L}=97.6 \mathrm{~km}$, which was achieved using FBG for dispersion 
pre- and post-compensation, but at $195.9 \mathrm{THz}$ the longest optical line was $\mathrm{L}=117.1$ $\mathrm{km}$, which was achieved using DCF for dispersion pre-compensation. When NRZ line code was used, the longest optical line for a single-channel system at $193.1 \mathrm{THz}$ was $\mathrm{L}=157.8 \mathrm{~km}$, but at $195.9 \mathrm{THz}, \mathrm{L}=148.7 \mathrm{~km}$ and the both results were achieved using DCF for dispersion pre-compensation.

For an 8-channel WDM system, the results were quite similar. All results for 8-channel system simulations are presented in Table 3. When RZ line code was used, the longest optical line using channel frequencies from 193.1 to $193.8 \mathrm{THz}$ was $\mathrm{L}=98.6 \mathrm{~km}$, but using $195.9-196.6 \mathrm{THz} \mathrm{L}=118.0 \mathrm{~km}$, and the both results were achieved using DCF for dispersion pre-compensation. When NRZ line code was used, the longest optical line using channel frequencies from 193.1 to $193.8 \mathrm{THz}$ was $\mathrm{L}=143.9 \mathrm{~km}$ and again this result was achieved using DCF for dispersion pre- compensation. However, using channel frequencies from 193.1 to $193.8 \mathrm{THz}$ the longest optical line was $\mathrm{L}=144.3 \mathrm{~km}$ when $\mathrm{FBG}$ was used for dispersion post-compensation.

Table 3

Maximal Provided Transmission Distances for 8-Channel Communication Systems with RZ and NRZ Line Codes

\begin{tabular}{|c|c|c|c|c|c|c|c|c|}
\hline \multicolumn{9}{|c|}{8 CHANNELS, RZ line code } \\
\hline 导 & U & 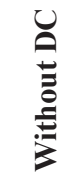 & 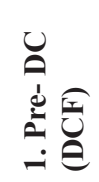 & 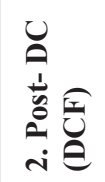 & 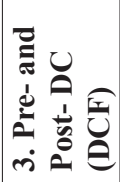 & 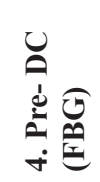 & 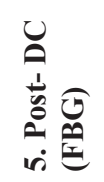 & 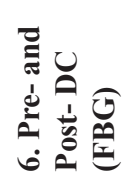 \\
\hline \multirow{3}{*}{$\begin{array}{l}\text { 193.1-193.8 } \\
\text { THz }\end{array}$} & Max. line length, km & 49.7 & 98.6 & 98.5 & 98.5 & 98.5 & 97.9 & 98.0 \\
\hline & Extension length, km & & 48.9 & 48.8 & 48.8 & 48.8 & 48.2 & 48.3 \\
\hline & Extension length, \% & - & 49.6 & 49.5 & 49.6 & 49.5 & 49.2 & 49.3 \\
\hline \multirow{3}{*}{$\begin{array}{l}\text { 195.9-196.6 } \\
\mathrm{THz}\end{array}$} & Max. line length, km & 56.1 & 118.0 & 117.6 & 117.9 & 115.9 & 115.7 & 115.7 \\
\hline & Extension length, km & & 61.9 & 61.5 & 61.8 & 59.8 & 59.6 & 59.6 \\
\hline & Extension length, \% & - & 52.5 & 52.3 & 52.4 & 51.6 & 51.5 & 51.5 \\
\hline \multicolumn{9}{|c|}{8 CHANNELS, NRZ line code } \\
\hline \multirow{3}{*}{$\begin{array}{l}\text { 193.1-193.8 } \\
\text { THz }\end{array}$} & Max. line length, $\mathrm{km}$ & 81.4 & 143.9 & 143.0 & 142.8 & 143.5 & 143.8 & 143.8 \\
\hline & Extension length, km & & 62.5 & 61.6 & 61.4 & 62.1 & 62.4 & 62.4 \\
\hline & Extension length, \% & - & 43.4 & 43.1 & 43.0 & 43.3 & 43.4 & 43.4 \\
\hline \multirow{3}{*}{$\begin{array}{l}\text { 195.9-196.6 } \\
\text { THz }\end{array}$} & Max. line length, km & 92.0 & 143.5 & 141.7 & 141.6 & 143.0 & 144.3 & 142.7 \\
\hline & Extension length, km & & 51.5 & 49.7 & 49.6 & 51.0 & 52.3 & 50.7 \\
\hline & Extension length, $\%$ & - & 35.9 & 35.1 & 35.0 & 35.7 & 36.2 & 35.5 \\
\hline
\end{tabular}

Tables 2 and 3 demonstrate by how much it is possible to extend the optical line, after performing DC for SMF. By comparing the length of extension fibres with the total length of fibres, it is possible to see which frequencies are affected more by dispersion. On average, for single-channel systems using $193.1 \mathrm{THz}$ channel central frequency, it was possible to extend optical line transmission length by $49.7 \%$ (DCF $-49.6 \%$, FBG $-49.7 \%$ ) but using $195.9 \mathrm{THz}$ by $51.5 \%$ (DCF - 51.6 \%, FBG $51.4 \%$ ) when RZ line code was used. When NRZ line code was used, it was possible 
to extend optical line transmission length by $46.3 \%$ (DCF $-46.5 \%$, FBG $-46.1 \%$ ) using $193.1 \mathrm{THz}$, and by $37.4 \%$ (DCF - 37.3 \%, FBG - 37.6 \%) using $195.9 \mathrm{THz}$.

From these results it was concluded that using $193.1 \mathrm{THz}$, optical fibre line extension would be by $1.8 \%$ shorter compared when $195.9 \mathrm{THz}$ was used with RZ line code. A completely opposite situation was observed when NRZ line code was used. Using $193.1 \mathrm{THz}$, optical fibre line extension was by $8.9 \%$ longer compared when $195.9 \mathrm{THz}$ was used.

For an 8-channel WDM system, a similar pattern was observed compared to a single-channel system. Using channel central frequencies from 193.1 to $193.8 \mathrm{THz}$ with RZ line code, the average line extension was $49.5 \%$ (DCF - 49.6\%, FBG $49.4 \%$ ), but using channel central frequencies from 195.9 to $196.6 \mathrm{THz}$ the average line extension was $52.0 \%$ (DCF - 52.4\%, FBG - $51.5 \%)$. However, when NRZ line code was used, the average line extension was $43.3 \%$ (DCF $-43.2 \%$, FBG $43.4 \%$ ) and $35.6 \%(\mathrm{DCF}-35.3 \%, \mathrm{FBG}-35.8 \%)$, respectively.

From these results it was concluded that using channel central frequencies from 193.1 to $193.8 \mathrm{THz}$, optical fibre line extension would be $2.5 \%$ shorter compared when 195.9 to $196.6 \mathrm{THz}$ was used with RZ line code. A completely opposite situation was observed when NRZ line code was used. When using channel central frequencies from 193.1 to $193.8 \mathrm{THz}$, optical fibre line extension was $7.7 \%$ longer compared when 195.9 to $196.6 \mathrm{THz}$ was used.

\section{CONCLUSIONS}

By using the investigated dispersion compensation methods, namely DCF and FBG, it was possible to compensate chromatic dispersion for single-channel and 8-channel optical WDM-PON transmission systems. On the basis of the obtained measurements for each simulated transmission system, the one dominant dispersion compensation method was observed. For single-channel systems where RZ and NRZ line codes were used for transmission on 193.1 THz and $195.9 \mathrm{THz}$ central frequencies, the longest optical fibre transmission distances were reached when DCF was used for dispersion pre-compensation. However, with one exception -when RZ line code was used on $193.1 \mathrm{THz}$, the longest optical fibre transmission distance was reached with FBG dispersion pre- and post-compensation method. Nevertheless, for single-channel WDM-PON systems it would be advisable to use dispersion pre-compensation with DCF to obtain maximal system performance.

Dispersion compensation by using DCF for pre-compensation in 8-channel systems also gave the longest optical fibre transmission distance in most simulation models. When RZ line code is used for the both channel frequency ranges, dispersion pre-compensation with DCF is advisable. However, when NRZ line code was used, dispersion pre-compensation with DCF gave the longest optical fibre transmission distance if channel central frequencies were set from 193.1 to $193.8 \mathrm{THz}$ with $100 \mathrm{GHz}$ channel spacing. When channel central frequencies were set from 195.9 THz to $196.6 \mathrm{THz}$, with the same channel spacing, then dispersion post-compensation with FBG gave the best result. It would be advisable to avoid dispersion post-compensation with FBG when 193.1-193.8 THz frequency range is used and 
pre- and post-compensation with DCF when 195.9-196.6 THz frequency range is used. In general, by using RZ line code it is possible to increase the total distance of optical fibre transmission lines by additional $3.4 \%$ for $193.1 \mathrm{THz}$ transmission frequency, comparing it with NRZ line code, but for $195.9 \mathrm{THz}$ even by $14.1 \%$. For an 8-channel system, this correlation remains valid - the usage of RZ line code will increase the total distance of optical fibre transmission by $6.2 \%$ when channel central frequencies are set from 193.1 THz to $193.8 \mathrm{THz}$ comparing with NRZ line code, but for channel central frequencies from $195.9 \mathrm{THz}$ to $196.6 \mathrm{THz}$ the total distance of optical fibre transmission will increase even by $16.4 \%$.

While it is possible to determine the best results from each individual transmission frequency range, generally using both dispersion compensation methods and DCM locations, it is possible to obtain similar results, but the recommended dispersion compensation method for single-channel and 8-channel transmission systems is DCF, especially, when it is used as a dispersion pre-compensation solution.

\section{REFERENCES}

1. Senior, M.J., \& Jamro, Y.M. (2009). Optical fibre communications principles and practice. Harlow, UK: Pearson Education Limited.

2. Chomycz, B. (2009). Planning fibre optic networks. USA: The McGraw-Hill Companies.

3. Ramaswami, K.R., Sivarajan, H., \& Sasaki, H.G. (2010). Optical Networks (3rd Edition). Burlington, UK: Elsevier.

4. Kashyap, R. (2010). Fibre Bragg gratings. London, UK: Elsevier.

5. Ajmani, M., \& Preeti, S.H. (2015). FWM in WDM system, effects and techniques to minimize: A review. In Fifth International Conference on Advanced Computing \& Communication Technologies, 21-22 February 2015 (pp. 385-389). Haryana, India: IEEE.

6. Bhusari, S.N., Deshmukh, V.U., \& Jagdale, S.S. (2016). Analysis of self-phase modulation and four-wave. In 2016 International Conference on Automatic Control and Dynamic Optimization Techniques (ICACDOT), 9-10 September 2016 (pp. 798-803). Pune, India: IEEE.

7. Kaminow, I.P., Li, T., \& Willner, A.E. (2008). Optical Fibre Telecommunications VB, Burlington, UK: Elsevier.

8. Frenzel, L.E. (2015). Handbook of serial communications interfaces. Kidlington, UK: Newnes.

9. Bobrovs, V., Porins, J., \& Ivanovs, G. (2007). Influence of nonlinear optical effects on the NRZ and RZ modulation signals in WDM systems. Electronics and Electrical Engineering, 4(76), 55-58. ISSN 1392-1215.

10. Singh, M. (2015). Analyzing the effect of channel spacing and chromatic dispersion coefficient on FWM in optical WDM system. International Journal of Signal Processing, 8(11), 99-110. ISSN: 2005-4254 IJSIP.

11. Spolitis, S., Bobrovs, V., \& Ivanovs, G. (2012). Investigation of high-speed AWG filtered spectrum-sliced WDM PON system. In 8th International Symposium on Communication Systems, Networks and Digital Signal Processing (CSNDSP), 18-20 July 2012. DOI: 10.1109/CSNDSP.2012.6292658. Poznan, Poland: IEEE. 


\author{
A. Alševska, V. Dilendorfs, S. Spolītis, Vj. Bobrovs
}

Kopsavilkums

Optisko šķiedru izmantošanai pārraižu sistēmās ir vairākas priekšrocības, piemēram, optisko šḳiedru kabeḷi izmantošana nodrošināt lielāku signālu joslas platumu, optiskais signāls necieš no citu signālu elektromagnētiskajiem traucējumiem un signāla vājinājums optiskajā šķiedrā ir mazāks nekā jebkurā citā pārraides vidē. Blīvuma viḷ,ngarumdales blīvēšana (DWDM) ir metode optisko pārraižu sistēmu veiktspējas palielināšanai, izmantojot optisko šķiedru efektīvāk - multipleksējot un vienlaikus pārraidot vairākus optiskos signālus ar dažādiem viḷnu garumiem optiskajā šķiedrā. Šajā rakstā autori salīdzina divu dispersijas kompensāciju metožu efektivitāti, vienkanāla un 8-kanālu, DWDM optisko šḳiedru pārraides sistēmām, izmantojot RZ un NRZ modulācijas formātus. Dispersijas kompensācija tiek realizētā izmantojot dispersiju kompensējošu šķiedru (DCF) un šķiedru Brega režǵi (FBG). Šī raksta galvenais mērķis ir noskaidrot dispersijas kompensācijas metodi - DCF vai FBG, kura nodrošina vislielāko šķiedru optiskās pārraides sistēmas veiktspējas pieaugumu un spēj vienlaikus nodrošināt visgarāko pārraides attālumu pēc dispersijas kompensācijas. Izmantojot abas pētītās dispersijas kompensācijas metodes, pilnībā bija iespējams kompensēt hromatisko dispersiju vienkanāla un 8-kanālu DWDM optiskajās pārraides sistēmās.

12.11.2017. 